UDC 378.091.33:004

DOI: $10.52534 / \mathrm{msu}-\mathrm{pp} .7(3) .2021 .55-61$

\author{
Alla V. Kozhevnikova ${ }^{\star}$, Natalia V. Merkulova, Yuliya I. Popeleshko, Natalia Ye. Rybka \\ Bohdan Khmelnytsky Melitopol State Pedagogical University \\ 72300, 20 Hetmanska Str., Melitopol, Ukraine
}

\title{
Information and Communication Technologies as Components of Effective Training Forms for Higher Education Applicants
}

\begin{abstract}
Article's History:
Received: 21.04.2021

Revised: 30.05 .2021

Accepted: 15.07.2021

\section{Suggested Citation:}

Kozhevnikova, A.V., Merkulova, N.V., Popeleshko, Yu.I., \& Rybka, N.Ye. (2021). Information and communication technologies as components of effective training forms for higher education applicants. Scientific Bulletin of Mukachevo State University. Series "Pedagogy and Psychology", 7(3), 55-61.
\end{abstract}

\begin{abstract}
The relevance of the issues regarding information and communication technologies as components of effective training forms for higher education applicants is determined by the need to introduce information and communication applications into the educational process. Accordingly, the purpose of the article is to provide theoretical justification and experimental verification of the impact that information and communication technologies have on improving the higher education quality for applicants. To achieve this purpose, a complex of modern general scientific methods was used: theoretical (analysis, synthesis, generalisation, comparison); empirical (questionnaires, conversations, interviews, observations, expert assessment); statistical research methods that facilitated the study of scientific sources on information and communication technologies. Based on the theoretical and methodological analysis of the studied issue, it is determined that information and communication technology is a means of joint activity for a teacher and a higher education applicant, which is characterised, primarily, by the consistency of actions (algorithmicity), constant and systematic evaluation of educational achievements and the development of educational qualities (diagnostics), the relationship of the main technology elements, namely the purpose, content, forms, methods, means of interaction, and the results (consistency) of participants in the educational process. It was discovered that to present the material more interestingly and motivate applicants for higher education, it is necessary to use innovative teaching forms and methods, one of which is information and communication applications that contribute to enhanced logical thinking, cognitive activity, the creativity of students and the comprehensive personality development of the future pedagogical specialist. It is proved that these applications contribute to the easier assimilation of new educational material, the creative performance of practical tasks, and productive cooperation between teachers and applicants for higher education. The practical value of the research lies in the fact that the results obtained can be used in further studies on the influence of information and communication technologies on the communication of the educational process subjects
\end{abstract}

Keywords: technology, information technologies, pedagogical technologies, information and communication applications

\section{INTRODUCTION}

Modern global changes contribute to the innovative development of higher education and require new approaches to presenting educational components of disciplines, as well as the introduction of the latest information and communication technologies. In the modern information society, an integral component of training applicants for higher education is the development of an information and communication culture among future specialists. Thus, in the context of reforming the Ukrainian education system, it is essential to become a qualified specialist of the appropriate level and profile, competitive in the labour market, competent, responsible, fluent in the profession, capable of effective work at the level of world standards, and ready for continuous professional improvement. However, the introduction of new information and communication technologies in the educational process causes numerous issues related to 
teaching methods, forms, and means, education humanitarisation and humanisation of the educational process, training and improving the professional qualifications of future teachers, their self-improvement and mastering the basics of modern information and communication technologies.

In modern psychological and pedagogical research, considerable attention is paid to introducing information and communication technologies in the educational process of higher educational institutions. Thus, information and communication technologies in education as a component of Ukrainian pedagogical science are analysed in the research by O. Voronkina [1] and O. Kolgatina [2], the specific features of educational technologies were investigated by M. Mikhailichenko and Ya. Rudik [3]; didactic conditions for the use of information and communication technologies in the organisation of independent educational activities of students are considered in the studies by O. Tsys [4]; training the future teachers to use information and communication technologies in professional activities is covered in the research by T. Shrol [5] and others.

Analysis of recent scientific publications indicates that the chosen issue has acquired a special status in the context of a pandemic $[4 ; 5]$. Notably, in the modern educational process of higher education institutions, communications are integral to information technologies, and information and communication technologies contribute to the effective organisation of training for higher education applicants. Due to the COVID-19 pandemic and the transition of higher education institutions to distance learning, teachers and applicants for higher education had to learn how to work online, which contributed to the introduction of new information and communication applications in the educational process. Thus, distance learning for higher education applicants was provided through the transmission of video, audio, graphic, and text information using a wide range of tools for educational interaction between participants in the educational process, namely: communication with users; passing courses with educational components (video lectures and video practical classes); reviewing the performance of higher education applicants, etc. For example, the Moodle platform is designed to combine subjects of the educational process into one reliable, secure, and integrated system to create an information and communication educational environment. At present, this platform is the most advanced and widespread both in Ukraine and in the world [6, p. 238].

It is also worth noting that distance learning contributes to familiarisation with the possibilities of using information and communication technologies in the teacher's professional activity; the development of students' information and communication competence and the ability to apply ICTs to solve various pedagogical situations.

The purpose of the article - theoretical justification and experimental verification of the impact that information and communication technologies have on improving the higher education quality for applicants. In accordance with the purpose of the article, the main tasks are:
1. Analyse the state processing the issues related to ICTs in the educational process of higher education institutions.

2. Clarify the essence of: "technology", "pedagogical technologies", "information technologies", "information and communication technologies".

3. To cover the effectiveness of information and communication applications and their impact on the educational process of higher education applicants.

4. Determine and experimentally test the organisational and pedagogical conditions for the cognitive activity development of higher education applicants within the introduction of information and communication applications.

\section{LITERATURE REVIEW}

It is worth starting with the fact that "technology" is of Greek origin: techne - art, skill, logos - science, law; the science of skill [7; 8]. In the explanatory dictionary, "technology" is presented as a set of techniques used in any business, skill, art [9, p. 1132]. For example, O. Kiyashko generally defines technology as "a set of methods, tools, and introduction of a specific complex process by dividing it into a system of sequential interrelated procedures and operations that are used more or less unambiguously and are aimed at achieving high efficiency of a certain type of activity" [10, p. 136]. Whereas according to E. de Bono, technology is the process of producing something useful based on the use of knowledge, and the main function of technology is to introduce theory into practice. This point of view is shared by Yu. Mashbyts who emphasised that teaching technologies are "a necessary link connecting pedagogical sciences with the teaching practice" [11, p. 24].

Notably, technology is covered from separate perspectives in the context of pedagogical technology. For instance, V. Bezpalko and M. Clarin define pedagogical technology as "a set of methods and functioning order of all personal, instrumental, and methodological means of reproducing theoretically based learning and mentoring to achieve the purpose and fulfil educational tasks", therewith, V. Monakhov considers pedagogical technology as an interaction model of all subjects in the educational process [12, p. 6]. S. Sysoeva indicates the general trend of transition to the interpretation of pedagogical technology as a pedagogical system, for this, modern pedagogical technology is interpreted as a system of the most rational ways to achieve a pedagogical purpose, the scientific organisation of the educational process at higher education institution [13, p. 286]. It should be emphasised that pedagogical technology is a teaching and educational system of personal and professional development, socialisation of a person in an educational institution [14, p. 39].

Evidently, modern pedagogical technologies cover the range of theoretical and practical issues related to management, educational process organisation, teaching methods and means at higher education institutions. For the author's research, this is of great importance, since information and communication technologies are innovative pedagogical technologies of the educational process, which consist in 
updating this process, contribute to more effective cooperation of subjects within it. Therewith, it is essential to cover the essence of "information technologies" and "information and communication technologies".

According to T. Vakaliuk and O. Spirin, "information technology in education is a set of educational and teaching materials, technical and instrumental means for educational purposes, as well as a system of scientific knowledge about the role and place of computer technology in the educational process, forms and methods of their application to improve cooperation between teachers and applicants for higher education" [15]. That is, it can be concluded that modern information technologies allow teachers and applicants for higher education to access media sources of information, increase the effectiveness of independent work, provide new opportunities for creativity, help to find and consolidate professional skills, and contribute to solving issues with new knowledge.

At last, the researchers O. Kolgatin and L. Kolgatina combined "information technologies" and "information and communication technologies" and provided a unified definition: a set of methods, production processes, and software and hardware tools integrated for the purpose of collecting, processing, storing, distributing, displaying, and using information" [2, p. 52]. Nevertheless, the authors of this study agree with a group of researchers that "information and communication technologies" should be considered from three perspectives:

- as information and computer technologies - software and hardware of personal computers, technologies for processing, storing, selecting and presenting information, the global computer network Internet, etc. [16, p. 125];

- as information and communication technologies data transmission technologies such as the Internet and mobile protocols and other communication types [17, p. 1250];

- as information and communication technologies communication in all its forms, including pedagogical communication [14, p. 295].

Notably, today Information and communication technologies are increasingly penetrating into various spheres of life, science, production, and education, which requires appropriate knowledge, skills, and abilities of their use and targeted development of information and communication competence. Summarising the above, information and communication technology is a way of interaction between subjects of the educational process and is characterised by systematic and consistent fulfilment of general and professional competencies.

\section{MATERIALS AND METHODS}

A set of modern general scientific methods was used to achieve purposes within this research:

- theoretical methods - analysis, synthesis, generalisation, comparison, which served to examine scientific sources on information and communication technologies;

- empirical methods (questionnaires, conversations, interviews, observations, expert assessment);
- statistical research methods that helped to identify the effectiveness of information and communication applications and their impact on the educational process of higher education applicants.

Methods of analysis, synthesis, generalisation, and comparison were applied for a more detailed study of scientific sources on "technology", "information technologies", "pedagogical technologies", "information and communication applications". Empirical research methods covered the influence of information and communication applications on the cognitive activity of higher education applicants. Thus, statistical research methods contributed to determining the selectiveness of observation results, their statistical parameters, basic principles, and criteria for their verification. Based on the above-mentioned methods, the research issues were comprehensively studied, data on information and communication technologies as components of effective training forms for higher education applicants were systematised.

The analysis of scientific sources made it possible to experimentally test the selected information and communication applications and their impact on the cognitive activity of higher education applicants. Research and experimental work were performed in accordance with the main requirements during the 2020-2021 academic year. In total, 78 students of the first (Bachelor's) level of higher education of Bogdan Khmelnitsky Melitopol State Pedagogical University participated in the experiment, out of all, 40 people were part of the control group (CG), for which an introductory lecture on information and communication applications and 6 practical classes with the use of applications were conducted: Rebus, Learning.ua, Quizizz, Kahoot, Quizlet, LearningApps.org; and 38 people were in the experimental group (EG), for which the entire course was conducted, it consisted of 12 lectures and 14 practical classes using the Kahoot information and communication applications, Quizlet, Rebus, Learning.ua, LearningApps.org., Quizizz.

The experimental work was performed in three stages: search-theoretical, experimental, and generalising. During the first (search-theoretical) stage, the state of processing the issue of information and communication technologies as a component of an effective training form for higher education applicants is determined. In the course of the second (experimental) stage, the organisational and pedagogical conditions were experimentally tested. The third (generalising) stage involved analysing the results of a scientific search.

Based on the theoretical analysis the necessary organisational and pedagogical conditions of the experiment were defined, namely: the purposes and motives aimed at the development of students' cognitive activity and need to use information and communication applications; selection of a special set of information and communication applications for increasing cognitive activity among higher education applicants; organisation of subject-subject interaction and its influence on students' cognitive activity. 


\section{RESULTS AND DISCUSSION}

The obtained results of the empirical stage indicate that the introduction of organisational and pedagogical conditions makes it possible to increase the cognitive activity among higher education applicants by implementing information and communication applications.

In the process of providing organisational and pedagogical conditions, the following criteria were selected: motivational, cognitive, activity, and reflexive. The first criterion was aimed at motivating people to obtain knowledge, skills, and abilities; achieving success in using information and communication applications. Thus, the cognitive criterion considers the system of knowledge about the cognitive activity among higher education applicants and the specific features of information and communication applications. The activity criterion provides for the application of professional and pedagogical skills; the practical use of information and communication applications. Whereas, the reflexive criterion is self-image, self-evaluation, self-interpretation, self-analysis, self-development skills within students' cognitive activity during the implementation of information and communication applications.

Notably, the characteristics of organisational and pedagogical conditions and criteria contributed to the identification of three levels of the studied issue: high, medium, and low. The low cognitive activity level among applicants for higher education is characterised by the reproduction of a small part of the main theoretical provisions, individual concepts without a sufficient understanding of the role of information and communication applications in the pedagogical process effectiveness; the ability to apply some elements of information and communication technologies in the educational process; interest in information and communication applications is only emerging. The medium level implies underdeveloped purposes and motives for using information and communication applications; the student obtains a common set of conventional methods, techniques, and teaching tools that are insufficient for the implementation of information and communication applications. Furthermore, this level is characterised by the acquisition of primitive skills such as copying, incomplete actions that applicants for higher education perform according to examples. A high level implies students' interest in an independent search for effective ways to use information and communication applications, in self-determination and awareness on the effectiveness of information and communication technologies, taking into account specific organisational and pedagogical conditions, implementation of practical actions in non-standard pedagogical situations.
According to the authors, to increase cognitive activity among higher education applicants during the introduction of information and communication applications the previously mentioned organisational and pedagogical conditions are required. Based on the considered criteria (motivational, cognitive, activity, reflexive), the levels and means of developing cognitive activity in using information and communication applications were identified. The information and communication applications were used during lectures and practical classes from a complex of selective and main educational components of academic disciplines: "pedagogy", "history of pedagogy", "inclusive pedagogy", "training technologies in preschool and inclusive education", "practical work with methods of preschool education".

The experimental work included the following empirical research methods: questionnaires, conversations, interviews, observations, and expert evaluation. Students of the experimental and control groups considered the main and selective educational components, as well as information and communication applications during the learning process:

1) the platform Kahoot! helps to test knowledge with game quizzes and tests;

2) the Quizlet app is a base for creating flashcards, training modules, and a service for developing interesting tests and flashcards. It should be emphasised that this application makes it possible to: prepare for exams and tests in memorisation mode; test memory; set records in the games; share cards with friends, teachers, or other students; listen to the correct pronunciation of texts in 18 languages; improve learning with images and audio;

3) learning.ua is an accessible database of exercises and tests of various fields;

4) the Quizizz is an English-language service for developing games, quizzes, tests, and surveys. The app is unique as it allows checking knowledge in a form of a test or questionnaire. The site has a lot of ready-made Ukrainian-language tests in various subjects;

5) the platform LearningApps.org is a constructor for interactive tasks and exercises in various fields, which provides an opportunity to prepare for external independent evaluation;

6) the Rebus is a system for creating useful puzzles, logic games, and interesting exercises.

Upon processing and studying the above applications, they were implemented in the educational process. Thereafter, a survey was conducted, in which applicants for higher education chose exactly the applications that they were most interested in, the results of the survey are presented in Table 1.

Table 1. Survey results on interest in information and communication applications among higher education applicants

\begin{tabular}{c|c|c} 
No. & App name & Number of votes \\
\hline 1. & Kahoot! & 19 \\
\hline 2. & Learning.apps & 14 \\
\hline 3. & Rebus & 11 \\
\hline 4. & Learning.ua & 8 \\
\hline 5. & Quizizz & 6 \\
\hline 6. & Quizlet & 6 \\
\hline
\end{tabular}


Upon analysing this table, it is evident that the multimedia application Kahoot! takes the first place and is quite relevant among students, it fully develops the cognitive activity of applicants for higher education. Notably, in studying the effectiveness of ICTs, information and communication applications were selected that can be used during classes of higher education applicants both in the classroom and remotely, and their benefits were analysed. Applicants for higher education were asked to choose the most effective application among all the proposed ones (there were 6 applications in total). These applications were used by higher education applicants in lectures, practical and seminar classes. The most popular ones are: "Kahoot!", "Learning.apps", "Rebus". Practical experience indicates that in the modern world there are quite common ICTs, as every teacher and higher education applicant has a phone which allows using information and communication applications at any time, both at home and in the classroom during training and teaching. It should be noted that information and communication applications, as a unique form of ICTs, contribute to creative cooperation between teachers and applicants for higher education during distance learning.

In the course of the research, the criteria and levels of processing the studied issue were diagnosed in the experimental and control groups (Table 2). The results of the experimental and control groups differ considerably after the empirical experiment stage. Based on the survey results, the authors discovered that students at the beginning of the research had an insufficient level of criteria for cognitive activity when using information and communication applications. For that reason, the effective resolution of the studied issue is possible only if certain interrelated organisational and pedagogical conditions are created. It should be noted that in implementing organisational and pedagogical conditions, the cognitive activity level among higher education applicants in the experimental group considerably increased.

Table 2. Manifestation levels of criteria on the students' cognitive activity level before the introduction of information and communication technologies to EG and CG (at the beginning and end of the experiment)

\begin{tabular}{|c|c|c|c|c|c|}
\hline \multirow[b]{2}{*}{ Criteria } & \multirow[b]{2}{*}{ Levels, \% } & \multicolumn{2}{|c|}{ Before the experiment } & \multicolumn{2}{|c|}{ After the experiment } \\
\hline & & $\begin{array}{c}\text { EG } \\
40 \text { people }\end{array}$ & $\begin{array}{c}\text { CG } \\
38 \text { people }\end{array}$ & $\begin{array}{c}\text { EG } \\
40 \text { people }\end{array}$ & $\begin{array}{c}\text { CG } \\
38 \text { people }\end{array}$ \\
\hline \multirow{3}{*}{ Motivational } & High & 18 & 19 & 54 & 26 \\
\hline & Medium & 30 & 32 & 32 & 47 \\
\hline & Low & 52 & 49 & 14 & 27 \\
\hline \multirow{3}{*}{ Cognitive } & High & 20 & 18 & 48 & 23 \\
\hline & Medium & 33 & 36 & 35 & 49 \\
\hline & Low & 47 & 46 & 17 & 28 \\
\hline \multirow{3}{*}{ Activity } & High & 11 & 12 & 54 & 14 \\
\hline & Medium & 29 & 30 & 35 & 47 \\
\hline & Low & 60 & 58 & 11 & 39 \\
\hline \multirow{3}{*}{ Reflexive } & High & 11 & 10 & 45 & 26 \\
\hline & Medium & 31 & 28 & 44 & 59 \\
\hline & Low & 58 & 62 & 11 & 15 \\
\hline
\end{tabular}

The experiment results on increasing cognitive activity of higher education applicants allowed presenting the general criteria levels of the experimental and control groups (Table 3). Upon comparing the results on the studied issue at the beginning and end of the experiment, quantitative and qualitative changes in both the experimental and control groups were indicated.

Table 3. The cognitive activity level of students before the introduction of ICTs to EG and CG (at the beginning and end of the experiment)

\begin{tabular}{|c|c|c|c|c|}
\hline \multirow{3}{*}{ Levels, \% } & \multicolumn{4}{|c|}{ Students } \\
\hline & \multicolumn{2}{|c|}{ Before the experiment } & \multicolumn{2}{|c|}{ After the experiment } \\
\hline & $\begin{array}{c}\text { EG } \\
40 \text { people }\end{array}$ & $\begin{array}{c}\text { CG } \\
38 \text { people }\end{array}$ & $\begin{array}{c}\text { EG } \\
40 \text { people }\end{array}$ & $\begin{array}{c}\text { CG } \\
38 \text { people }\end{array}$ \\
\hline High & 15 & 15 & 50 & 22 \\
\hline Medium & 31 & 32 & 37 & 51 \\
\hline Low & 54 & 53 & 13 & 27 \\
\hline
\end{tabular}


Comparative analysis shows that the cognitive activity level of higher education applicants before the introduction of information and communication applications according to four criteria in the experimental group increased from low (54\%) to high (50\%); in the control group, the indicator increased from low (53\%) to average (51\%).

Thus, information and communication applications enhance students' logical thinking, cognitive activity, creativity, and contribute to the comprehensive personality development of a future specialist in the pedagogical field. As a result of the introduction of these applications, the higher education applicant learns new educational material more easily and with interest, which promotes creativity when completing tasks of selective and main components of disciplines.

\section{CONCLUSIONS}

Summarising the above, the use of information and communication applications in the educational process of higher education institutions considerably increases the efficiency of material assimilation by higher education applicants and motivates them to create research and project works with multimedia presentations. Thus, the use of ICTs reflects the teachers' skills, whereas their individual methods, techniques, and forms of training and mentoring influence the personal development level of higher education applicants. The analysis of ICTs as effective training forms for higher education applicants at the present stage allowed asserting that their introduction is a complex, dynamic, continuous process, and requires considering requirements for informatisation of education and society. Therefore, the fulfilment of research tasks made it possible to achieve its purpose - theoretically justify and experimentally test the impact of information and communication technologies on improving the education quality of higher education applicants.

The authors emphasise that in the course of the study, organisational and pedagogical conditions for the cognitive activity growth among higher education applicants in the conditions of introducing information and communication applications were developed. The study determined the organisational and pedagogical conditions that interact, organically complement each other, and are aimed at establishing the main components of the studied process. These conditions consist in the targeted influence on the criteria (motivational, cognitive, activity, and reflexive) and provide for the use of various information and communication applications. The effectiveness of the proposed methodology is proved by a considerable increase in the cognitive activity levels among students before the introduction of information and communication applications. In the experimental group, the generalised indicator of the students' cognitive activity in the conditions of ICTs introduction increased from low to high, and in the control group - from low to medium.

The conducted research does not cover all aspects of introducing information and communication applications in higher education institutions. Promising areas of research include the impact of information and communication applications on the interaction between teachers and applicants for higher education.

\section{REFERENCES}

[1] Voronkin, O.S. (2016). Information and communication technologies as a key factor of innovative development of higher education: Global dimension. Information Technologies and Learning Tools, 55(5), 12-30.

[2] Kolhatin, O.H., \& Kolhatina, L.S. (2019). Information and communication technologies in education as a part of Ukraine pedagogical science in the field of theory of pedagogics in the $90^{\text {th }}$ years of the $20^{\text {th }}$ century. Information Technologies and Learning Tools, 72(4), 41-54.

[3] Mykhailichenko, M.V., \& Rudyk, Ya.M. (2016). Educational technologies. Kyiv: Komprynt.

[4] Tsys, O.O. (2018). Didactic conditions of application of information and communication technologies in the organization of independent educational activity of students of technological and pedagogical specialties (Candidate thesis, Ternopil Volodymyr Hnatiuk National Pedagogical University, Ternopil, Ukraine).

[5] Shrol, T.S. (2020). Blended learning as a basis for the formation of ICT competence of future mathematics teachers. In I.S. Voitovych (Ed.), Preparation of future teachers for the use of information and communication technologies in professional activities (pp. 136-160). Lutsk: Volynpolihraf.

[6] Kukharenko, V.M., \& Bondarenko, V.V. (Eds.). (2020). Emergency distance learning in Ukraine. Kharkiv: "Miska drukarnia".

[7] Kremen, V.H. (Ed.). (2008). Encyclopedia of education. Kyiv: Yurinkom Inter.

[8] Navolokova, N.P. (Ed.). (2012). Encyclopedia of pedagogical technologies and education. Kharkiv: Publishing Group "Osnova".

[9] Busel, V.T. (Ed.). (2001). Great explanatory dictionary of modern Ukrainian language. Kyiv, Irpin: Perun.

[10] Kiiashko, O.O. (2001). Innovative pedagogical technologies for training junior specialists in higher educational institutions of I-II levels of accreditation. (Candidate dissertation, Luhansk Taras Shevchenko National University, Luhansk, Ukraine).

[11] Danylenko, L.I. (2004). Management of innovation activity in secondary schools. Kyiv: Milenium.

[12] Dychkivska, I.M. (2004). Innovative pedagogical technologies. Kyiv: Akademvydav.

[13] Hurevych, R.S. (Ed.). (2012). Information technologies in learning: Innovative approach. Vinnytsia: "Planer".

[14] Kovach, V.O. (2019). Information and communication technologies in education. Kyiv: Komprynt. 
[15] Spirin, O.M., \& Vakaliuk, T.A. (2019). Formation of information and communication competence of bachelors of informatics on the use of cloud-oriented learning environment. Information Technologies and Learning Tools, 72(4), 226-245.

[16] Vakaliuk, T.A., Antoniuk, D.S., \& Soloviev, V.N. (2019). The state of ICT implementation in institutions of general secondary education: A case of Ukraine. Proceedings of the $7^{\text {th }}$ Workshop on Cloud Technologies in Education, 2643, 119-133.

[17] Pochtovyuk, S.I., Chernenko, V.P., \& Valaliuk, T.A. (2020). Information and communication technologies in the study of mathematical methods in psychology. Proceedings of the $16^{\text {th }}$ International Conference on ICT in Education, Research and Industrial Applications, 2732, 1249-1259.

\section{Алла Власівна Кожевникова, Наталя Володимирівна Меркулова, Юлія Іванівна Попелешко, Наталія Євгенівна Рибка}

Мелітопольський державний педагогічний університет імені Богдана Хмельницького 72300, вул. Гетьманська, 20, м. Мелітополь, Україна

\section{Інформаційно-комунікаційні технології як складові ефективних форм навчання здобувачів вищої освіти}

Анотація. Актуальність проблеми інформаційно-комунікаційних технологій як складових ефективних форм навчання здобувачів вищої освіти визначається потребою у впровадженні в навчальний процес інформаційнокомунікаційних додатків. Відповідно, метою статті $є$ теоретичне обгрунтування та експериментальна перевірка впливу інформаційно-комунікаційних технологій на підвищення якості навчання здобувачів вищої освіти. Для реалізації мети було використано комплекс сучасних загальнонаукових методів: теоретичні методи (аналіз, синтез, узагальнення, зіставлення); емпіричні методи (анкетування, бесіда, інтерв'ювання, спостереження, експертне оцінювання);статистичні методи дослідження, що послугували вивченню наукових джерел щодо інформаційно-комунікаційних технологій. На основі теоретико-методологічного аналізу досліджуваної проблеми визначено, що інформаційно-комунікаційна технологія є способом спільної діяльності викладача та здобувача вищої освіти, для якого притаманні, передусім, послідовність у реалізації дій (алгоритмічність), постійне і систематичне вимірювання рівня навчальних досягнень і сформованості виховних якостей (діагностичність), взаємозв'язок основних елементів технології, якими є мета, зміст, форми, методи, засоби взаємодії та результат (системність) учасників освітнього процесу. З’ясовано, що для того, щоб цікавіше подати матеріал та мотивувати здобувачів вищої освіти, необхідно використовувати інноваційні форми та методи навчання, одними 3 яких $€$ інформаційно-комунікаційні додатки, які сприяють розвитку логічного мислення, пізнавальної активності, креативності в студентів та всебічному розвитку особистості майбутнього педагогічного фахівця. Обгрунтовано, що використання цих додатків сприяє полегшеному засвоєнню нового навчального матеріалу, креативному виконанню практичних завдань й плідній співпраці викладача та здобувачів вищої освіти. Практичне значення роботи полягає в тому, що отримані результати можуть бути використані у подальших дослідженнях впливу інформаційно-комунікаційних технологій на процес комунікації суб’єктів освітнього процесу

Ключові слова: технологія, інформаційні технології, педагогічні технології, інформаційно-комунікаційні додатки 